\title{
The Effect of Service Quality and Facilities on Patient Satisfaction
}

\section{(Study at the Tanah Sepenggal Health Center in Bungo District)}

\author{
Tarjo \\ Lecturer of Business Administration Study Program \\ College of Admnistrative Sciences Setih Setio Muara Bungo, Jambi, Indonesia \\ E-mail: tarjuly4@gmail.com
}

Received: Nov. 1, 2019 Accepted: Jul. 27, 2020 Online published: Aug. 6, 2020

doi:10.5296/ijhrs.v10i3.15744 URL: https://doi.org/10.5296/ijhrs.v10i3.15744

\begin{abstract}
This study was to examine and explain the effect of service quality and facilities on patient satisfaction in the Tanah Sepenggal Community Health Center in Bungo Regency, Jambi Province. The research method used is cross-sectional. The study population was all patients while the sample was 120 respondents but 98 respondents could be tested because there were 22 instruments that were not filled in completely so they were not included in the analysis. The sampling technique uses confinance sampling. The data analysis method uses multiple linear regressions with the help of the IBM SPSS Statistics version 20 of the software.

The statistical test results partially service quality variables consisting of tangible (X1), reliability (X2) responsiveness (X3) assurance (X4) empathy (X5) have no significant effect on patient satisfaction and facilities (X6) have a significant positive effect on patient satisfaction. Statistical test results simultaneously have a positive and significant effect on patient satisfaction.
\end{abstract}

Keywords: service quality, facilities and patient satisfaction

\section{Introduction}

Health services are the most basic needs of every human being, therefore it is the responsibility of the state, this is stated in the Regulation of the Minister of Health of the Republic of Indonesia. Number. 4 of 2019 concerning technical standards to meet basic 
service quality is called minimum service standards. The quality of service from each type of basic health service consists of the number of standards and the quality of goods and / or services, the number and quality of health workers/human resources and the technical standards of compliance.

Health is a basic right of every Indonesian citizen in the territory of the Republic of Indonesia. The government as an institution whose main goal is to provide public services for all levels of society. One of the public services is health services for the community, health services are obtained through public hospitals and community health centers (puskesmas). Health centers as part of government institutions have the task of health services in rural and urban areas as an extension of government at the village level. The government wants to realize the needs of the community about the importance of health. Health is the main capital to build the nation, the nation will become advanced if the community is healthy. Like previous research that the state will succeed if the community is healthy, if the healthy community they contribute a lot to contribute their thinking to the state (Rehaman B, 2018).

To realize the right to health for the community, service providers must provide quality services, so that what has been received can really be felt by patients. The quality of health care is the patient's right, because the patient has paid as a form of health facility so that the community gets good service, so with the costs incurred by the patient it is hoped that he will get a comparable service (Andaleeb, 2001). Quality of service to create different values in increasing customer satisfaction. Customers are willing to pay more so that the sacrifice is not in vain, so that with quality service the customer has a value of pride and those who can feel it (Kazemi et al., 2013).

Research conducted to measure service quality using models from Parasuraman, SERQUAL with 5 dimensions, the results of previous studies there are differences (Yunus et al., 2013); (Aliman \& Mohamad, 2016); (Kazemi et al., 2013); (Martins et al., 2015) in addition to measuring patient satisfaction is also influenced by facilities (Javed et al., 2019).

This research was conducted by maintaining these five dimensions by adding facilites variables. Community health centers is a district/city health technical implementing unit responsible for implementing health development in the work area (Indonesia, 2016). Tanah Sepenggal Health Center, located in Lubuk Landai Tanah Sepenggal sub-district, Bungo Regency, Jambi Province

\section{Literature Review}

\section{Service of Quality}

Service quality is difficult to measure because it has special uniqe characteristics, service quality is related to perceptions that compare expectations and perceptions. If the service is in accordance with what is expected then the perception will be good but if the service provided is not in accordance with the expectations, the perception will be not good (Krishna Naik et al., 2010). Patients who feel satisfied with the services provided will save time in handling complaints (Kazemi et al., 2013) the quality of service becomes very important for customers or users of suits (Alghamdi, 2014); (Kheng et al., 2010). 
Service quality of using the SERVQUAL concept developed by Parasuraman, Zeithaml is widely used in some literature, which is generally to measure customer satisfaction in the banking world but in the public area is directly related to many people such as the health service sector many use this concept, service quality is influenced by factors age, place of residence and education (Martins et al., 2015) are the final outcomes that are related and dependency between various components. The quality of health care is the level where it can meet good professional standards in patient care and the realization of the end results as expected with regard to care, diagnosis, action, and technical problem solving.

The concept of service quality has an important role in the service sector, because with quality services, the organization has competitiveness because it provides services that exceed customer expectations, health services are provided to meet the needs of the community and can overcome the problems faced (Yunus et al., 2013). Service quality provides a major impact on the development of an organization, besides that service quality is contributing to increasing revenue for private hospitals if customer satisfaction can be realized (Aliman \& Mohamad, 2016).

The quality of services provided by hospitals is the result of evaluations of all users received and provided by the organization, then the quality of services that emphasizes total quality oriented to health care and ultimately to hospital performance (Lim et al., 2018) service quality determines customer satisfaction and becomes a strength and becomes the basis of competition in order to retain customers (Rahmani-Nejad et al., 2014) service quality is a measure of the level of service provided in accordance with customer expectations (Nyoman et al., 2019).

Quality of service, quality of treatment is an important factor in increasing patient satisfaction, medical personnel are the key determinant of patient satisfaction, therefore hospitals must better understand what patients need (Li et al., 2015) quality of service is the differentiator which is profitable and difficult to be imitated by competitors, the concept of health services that becomes an advantage in competing with selling services (Zarei et al., 2012).

Patient satisfaction is still a lot of debate in general because it relates to the patient's health rights. The concept of patient satisfaction becomes an input in determining strategies to improve public health, which is an important indicator for policy makers derived from patient complaints. Patient satisfaction is the responsibility of the state in its implementation which is the right of every citizen (Mpinga \& Chastonay, 2011). Patient satisfaction is the goal of the most basic service, patient satisfaction will be useful for evaluating the results of health care, whether or not someone is satisfied will be seen from their behavior, patients who are satisfied will obey the advice of doctors also recommend to others (Kazemi et al., 2013).

Patient satisfaction is a benchmark in assessing patient satisfaction to compare between patient needs and expectations. Patient satisfaction will be manifested from the quality of services that affect patient health. Patient satisfaction will reduce the level of complaints, patient satisfaction is caused by several things including gender, nurses and doctors' attitudes (Chen et al., 2016).

Patient satisfaction is a major concern in providing health services in order to improve the 
quality and effectiveness of services (Ayranci \& Atalay, 2019). Patient satisfaction is also a major concern and priority in the health system. Patient satisfaction depends on each patient's perception related to their expectations of how they assess the quality and quantity of health care services. Patient satisfaction is a cognitive response. Many factors that cause patient anxiety include awareness of service quality, policy makers, waiting time, including nurses and doctors medical personnel and patient care costs (Farzianpour et al., 2015) (Farzianpour et al., 2015 deleted because of double). Patient satisfaction is largely influenced by the quality of the services provided, therefore it must be the main priority for the hospital (Alghamdi, 2014).

To measure service quality using the concept of Parasuraman (Rehaman B, 2018); (Rashidi $\&$ Sarayreh, 2019) measured by 5 (five) indicators as follows:

Tangible

Real proof is the company's ability to show its existence to outside parties. The appearance and capabilities of the company's physical infrastructure and advice that can be relied on by the environment around it are tangible evidence of the services provided by the service provider. Including physical facilities (buildings, warehouses), equipment and equipment used (technology), appearance.

Reliability

The ability to provide timely and accurate services as specified. namely the willingness of officers to provide fast services according to procedures and be able to meet customer expectations.

Responsiveness

Responsiveness is the level of willingness to help and facilitate patients or consumers by providing services that are appropriate for consumption, a willingness to help customers and provide services quickly or responsively

Assurance

Relating to the patient's sense of security and comfort because the patient's confidence in the officer who has competence, credibility and the right skills in providing services and patients will be guaranteed safe and comfortable services. Guarantees / beliefs include the ability of employees to know the right products / services, quality hospitality, attention and courtesy in providing services, skills in providing information, ability to provide security in utilizing the services offered, and the ability to instill confidence in patients in hospital services.

Empathy

Care and attention of officers for each patient by listening to complaints and understanding the needs and provide comfort for all patients in contacting the officer. Patients as sick people generally expect attention from the people around them. Empathy is the attention given by service providers to patients. 


\section{Ml Macrothink}

Facilities

Facilities are defined as everything to support the convenience of consumers provided/prepared by service providers/institutions in the form of physical equipment. Service purchase transactions, in some types of services, perceptions / picture patterns of interactions between service users and facilities will have a significant effect on service quality in the eyes of service users. Facilities which differentiate between government hospitals and private hospitals; facilities that become a patient's concern are costs (Javed et al., 2019); (Ayranci \& Atalay, 2019).

Patient Satisfaction

Satisfaction is a positive attitude in a person, basically satisfaction is something that is individual. Each individual will have a different level of satisfaction according to the value system that applies to him. Satisfaction as an individual judgment is collected from several experiences regarding objects or events experienced from time to time. Satisfaction is defined as a condition that is felt by someone both in the form of pleasure and displeasure which is then compared to what is expected. Patient satisfaction has an impact (Mpinga \& Chastonay, 2011) in addition to patient satisfaction due to the behavior of health workers such as doctors, hospital features (Ayranci \& Atalay, 2019) factors that determine patient satisfaction are demographic factors and information system factors and appropriate service planning (Farzianpour et al., 2015); (Chen et al., 2016); (Martins et al., 2015) patient satisfaction is an important factor and therefore needs organizational commitment to work quality (Mrayyan, 2006) Changes in employee behavior can increase satisfaction by utilizing the resources owned (Hoodbhoy et al., 2020).

Many patients' satisfaction is influenced by several factors of employee attitudes, capacity in providing fast services without wasting time and ability to provide information and equipment availability (Issadeen et al., 2019). Customer perception of the quality of the product or service brings satisfaction in the customer's mind. Health services, patients are seen as health service customers who consciously make the choice to use services that best suit their needs.

Based on the background of the problem above, the models of concept of this study are as follows: 


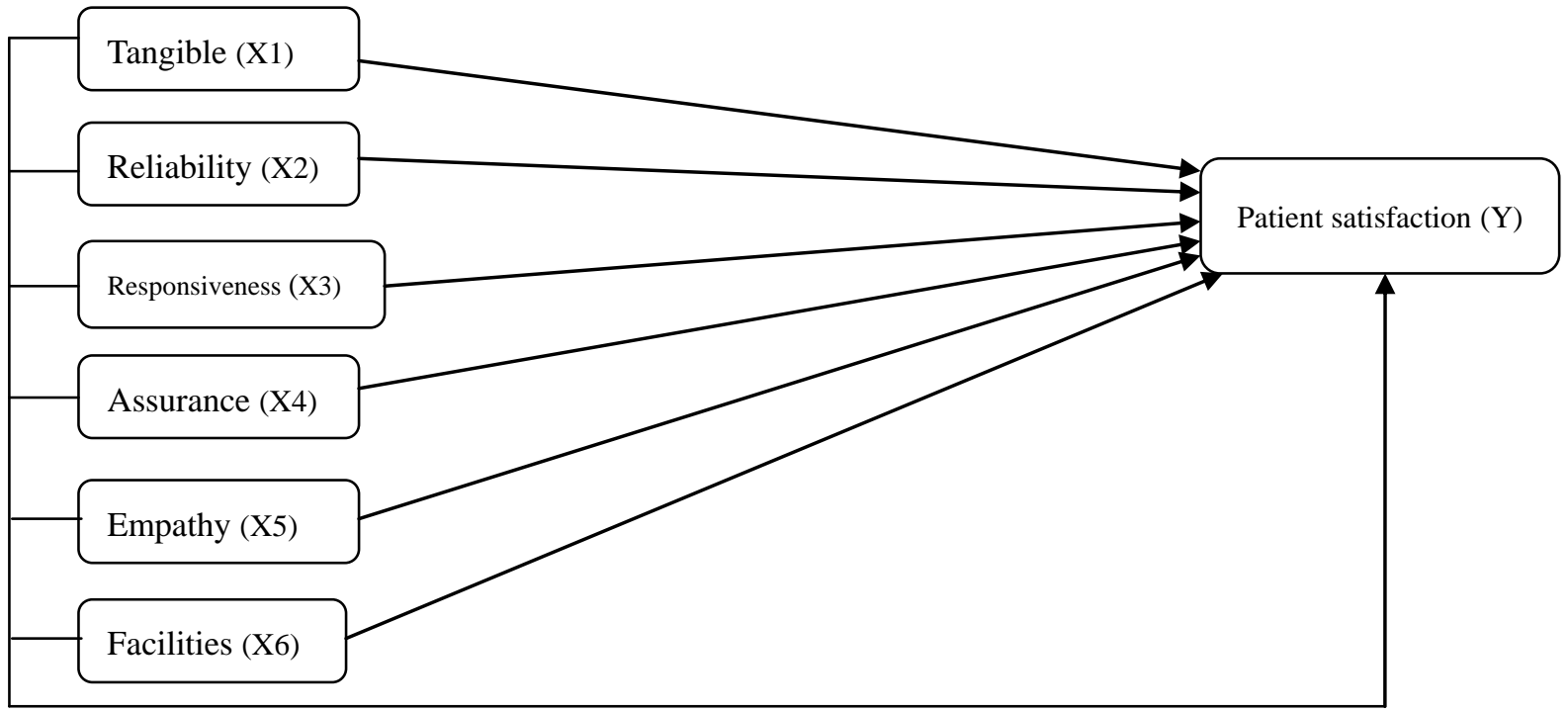

Figure 1. Research concept models

\section{Research Hypothesis}

Based on the background of the problem mentioned above, the concept model and hypothesis of this study are as follows:

H1: There is a significant positive effect tangible on patient satisfaction

$\mathrm{H} 2$ : There is a significant positive effect reliability on patient satisfaction

$\mathrm{H} 3$ : There is a significant positive effect responsiveness on patient satisfaction.

$\mathrm{H} 4$ : There is a significant positive effect assurance on patient satisfaction.

H5: There is a significant positive influence empathy on patient satisfaction

H6: There is a significant positive effect facilities on patient satisfaction

H7: There is a significant positive effect between tangible reliability, responsiveness, assurance, empathy and facilities on patient satisfaction

\section{Research Method}

This research is a cross-sectional study. The study population was all patients seeking treatment at the community health center. The research sampling method uses convinance sampling (Alghamdi, 2014); (Aziz-Ur-Rehman \& Siddiqui, 2019) by distributing 120 questionnaires while 98 questionnaires can be tested the remaining 22 are incomplete so the research sample is $82 \%$. Data collection techniques using questionnaires, data analysis in this study using multiple linear regression with IBM SPSS Statistics version. 20

Validity Test according to Sudjana (in Tarjo, 2019) states that validity is to ensure that the concept of appraisal is appropriately assessed so that it truly evaluates as it should. So the validity test is a test tool/ research instrument that will be used correctly that meets the criteria. The Sudjana reliability test (in Tarjo, 2019) states that the reliability of an appraisal tool is the accuracy or consistency of the tool used in its valuation. That is, each time the assessment or test equipment used will give results that are relatively the same or still within the specified limits. 


\section{Macrothink \\ International Journal of Human Resource Studies \\ ISSN 2162-3058 2020, Vol. 10, No. 3}

Multiple Linear Regression Analysis Test.

Multiple linear regression is testing the effect of more than two independent variables on the dependent variable, this model is used to form a regression equation. This regression analysis is not only to estimate test results but also to draw conclusions from true values (Ghozali, 2009).

\section{Results and Discussion}

\section{Characteristics of Respondents}

Table 1. Characteristics of Respondents

\begin{tabular}{llll}
\hline Description & Alternative & F & $\%$ \\
\hline Sex & Male & 55 & 56,1 \\
& Female & 43 & 43 \\
age & 26 - 30 years & 11 & 11,2 \\
& 31- 40 years & 9 & 9,2 \\
& 41- 50 years & 31 & 31,6 \\
& 51- 60 years & 28 & 28,6 \\
& $>61$ years & 19 & 19,4 \\
Education & & & \\
& Elementary & 3 & 3,1 \\
& Middle School & 26 & 26,5 \\
& High School & 54 & 55,1 \\
& Diploma & 12 & 12,2 \\
& Bachelor & 3 & 3,1 \\
Medical Needs & Children & & \\
& Mature & 4 & 4,1 \\
& Elderly & 92 & 93,9 \\
\hline
\end{tabular}

Source: Data processed, 2019

Table 1 characteristics of male respondents as many as 55 people or $56.1 \%$, female respondents 43 people or $43.9 \%$. Characteristics of respondents based on age 26-30 years amounted to 11 people or $11.2 \%$, respondents aged $31-40$ years were 9 people or $9.2 \%$, aged $41-50$ years amounted to 31 people or $31.6 \%$, aged 51-60 28 people or $28.6 \%$, aged > 61 years were 19 people or $19.4 \%$.

Characteristics of respondents according to basic education amounted to 3 people or $3.1 \%$, junior high school education totaled 26 people or $26.5 \%$, secondary school education totaled 54 people or $55.1 \%$, Diploma as many as 12 people or $12.2 \%$ and undergraduate a total of 3 people or $3.1 \%$.

Characteristics of respondents for the medical needs of children as many as 4 people or $4.1 \%$. 92 adults or $93.9 \%$ and elderly totals 2 or $2 \%$. 
Validity test

Table 2. Test Validity Service Quality Variable

\begin{tabular}{|c|c|c|c|c|}
\hline Variable & Indicator & rcount & rtable & desc \\
\hline Tangible & $\begin{array}{l}\text { 1. Type of equipment } \\
\text { 2. Payment points that are easy to reach } \\
\text { 3. Facilities provided } \\
\text { 4. The tidiness of the officers } \\
\text { 5. Brochure material }\end{array}$ & $\begin{array}{l}0,517 \\
0,508 \\
0,448 \\
0,630 \\
0,693\end{array}$ & $\begin{array}{l}0,196 \\
0,196 \\
0,196 \\
0,196 \\
0,196\end{array}$ & $\begin{array}{l}\text { Valid } \\
\text { Valid } \\
\text { Valid } \\
\text { Valid } \\
\text { Valid }\end{array}$ \\
\hline Reliability & $\begin{array}{l}\text { 6. The accuracy of keeping promises in service } \\
\text { 7. Timeliness in service } \\
\text { 8. Conformity in the implementation of services } \\
\text { 9. Concern for customers } \\
\text { 10. Seriousness in service }\end{array}$ & $\begin{array}{l}0,672 \\
0,665 \\
0,712 \\
0,567 \\
0,577\end{array}$ & $\begin{array}{l}0,196 \\
0,196 \\
0,196 \\
0,196 \\
0,196\end{array}$ & $\begin{array}{l}\text { Valid } \\
\text { Valid } \\
\text { Valid } \\
\text { Valid } \\
\text { Valid }\end{array}$ \\
\hline $\begin{array}{l}\text { Responsivenes } \\
\mathrm{s}\end{array}$ & $\begin{array}{l}\text { 11. clarity of information } \\
\text { 12. speed of service } \\
\text { 13. service accuracy } \\
\text { 14. willingness to help } \\
\text { 15. willingness to respond }\end{array}$ & $\begin{array}{l}0,702 \\
0,556 \\
0,365 \\
0,612 \\
0,638\end{array}$ & $\begin{array}{l}0,196 \\
0,196 \\
0,196 \\
0,196 \\
0,196\end{array}$ & $\begin{array}{l}\text { Valid } \\
\text { Valid } \\
\text { Valid } \\
\text { Valid } \\
\text { Valid }\end{array}$ \\
\hline Assurance & $\begin{array}{l}\text { 16. trust } \\
\text { 17. sense of secure } \\
\text { 18. convenience } \\
\text { 19. courtesy } \\
\text { 20. Guarantee }\end{array}$ & $\begin{array}{l}0,317 \\
0,493 \\
0,589 \\
0,530 \\
0,706\end{array}$ & $\begin{array}{l}0,196 \\
0,196 \\
0,196 \\
0,196 \\
0,196\end{array}$ & $\begin{array}{l}\text { Valid } \\
\text { Valid } \\
\text { Valid } \\
\text { Valid } \\
\text { Valid }\end{array}$ \\
\hline Emphaty & $\begin{array}{l}\text { 21. Individual attention } \\
\text { 22. Comfortable operating hours } \\
\text { 23. Understanding specific needs } \\
\text { 24. Build interest } \\
\text { 25. Suitability of working hours }\end{array}$ & $\begin{array}{l}0,730 \\
0,683 \\
0,524 \\
0,662 \\
0,390\end{array}$ & $\begin{array}{l}0,196 \\
0,196 \\
0,196 \\
0,196 \\
0,19 \\
\end{array}$ & $\begin{array}{l}\text { Valid } \\
\text { Valid } \\
\text { Valid } \\
\text { Valid } \\
\text { Valid }\end{array}$ \\
\hline
\end{tabular}

Source: Data processed 2019

Table 3. Test Validity Facilities Variables

\begin{tabular}{lllll}
\hline Variable & \multicolumn{1}{c}{ Indicator } & rcount & rtable & Desc \\
\hline Facilities & $\begin{array}{l}\text { 1. Completeness of medical equipment } \\
\text { 2. The comfort of the waiting room }\end{array}$ & 0,648 & 0,196 & Valid \\
& $\begin{array}{l}\text { 3. Using a queue number. } \\
\text { 4. Adequate seating. }\end{array}$ & 0,820 & 0,196 & Valid \\
& & 0,365 & 0,196 & Valid \\
& & 0,843 & 0,196 & Valid \\
\hline
\end{tabular}

Source: Data processed 2019 
Table 4. Test Validity Patient Satisfaction Variable

\begin{tabular}{llccc}
\hline \multicolumn{1}{c}{ Variable } & \multicolumn{1}{c}{ Indicator } & rcount & rtable & Desc \\
\hline Patient & $\begin{array}{l}\text { 1. The expected quality of service is satisfying } \\
\text { Satisfaction }\end{array}$ & 0,727 & 0,215 & Valid \\
& $\begin{array}{l}\text { 2. Community Health centers facilities support } \\
\quad \text { satisfaction }\end{array}$ & 0,768 & 0,215 & Valid \\
& $\begin{array}{l}\text { 3. Prices are in accordance with the services provided } \\
\text { 4. Good institutional image }\end{array}$ & 0,271 & 0,215 & Valid \\
& 5. Re-use services. & 0,453 & 0,215 & Valid
\end{tabular}

Source: Data processed 2019

Reliability Test

Table 5. Reliability Test

\begin{tabular}{clrrl}
\hline No & Variable & rcount & rtable & description \\
\hline 1 & Tangible & 0,490 & 0,215 & Reliabel \\
2 & Reliability & 0,626 & 0,215 & Reliabel \\
3 & Responsiveness & 0,466 & 0,215 & Reliabel \\
4 & Assurance & 0,500 & 0,215 & Reliabel \\
5 & Empathy & 0,372 & 0,215 & Reliabel \\
6 & Fasilities & 0,603 & 0,215 & Reliabel \\
7 & Patient Satisfaction & 0,359 & 0,215 & Reliabel \\
\hline
\end{tabular}

Source: Data processed 2019

\section{Coefficient of Determination $\left(\mathbf{R}^{2}\right)$}

Table 6. Test the coefficient of determination $\left(\mathrm{R}^{2}\right)$

Model Summary

\begin{tabular}{|l|r|r|r|r|}
\hline Model & R & R Square & Adjusted R Square & Std. Error of the Estimate \\
\hline 1 & $.590^{\mathrm{a}}$ & .348 & .306 & 1.069 \\
\hline
\end{tabular}

a. Predictors: (Constant) tangible, reliability, responsiveness, assurance, empathy, fasilities

Based on table 6 the coefficient of determination test, Adjusted RSquare value of 0.348 multiplied by $100 \%$ obtained a value of $34.8 \%$ which means that the variable quality of service and facilities can explain patient satisfaction by $34.8 \%$ and the rest is influenced by other variables not examined. 


\section{T test (Partial Test)}

Table. 7 Test $\mathrm{t}$ (Partial Test)

\section{Coefficients $^{\mathrm{a}}$}

\begin{tabular}{|c|c|c|c|c|c|c|}
\hline \multicolumn{2}{|c|}{ Model } & \multicolumn{2}{|c|}{ Unstandardized Coefficients } & \multirow{2}{*}{$\begin{array}{c}\text { Standardized } \\
\text { Coefficients }\end{array}$} & \multirow[t]{2}{*}{$\mathrm{t}$} & \multirow[t]{2}{*}{ Sig. } \\
\hline & & B & Std. Error & & & \\
\hline \multirow{7}{*}{1} & (Constant) & 11.468 & 3.371 & & 3.402 & .001 \\
\hline & Tangible & .070 & .091 & .075 & .767 & .445 \\
\hline & Reliabitity & .042 & .079 & .054 & .525 & .601 \\
\hline & Responsiveness & -.023 & .095 & -.026 & -.247 & .805 \\
\hline & Assurance & -.031 & .129 & -.024 & -.239 & .811 \\
\hline & Empathy & .086 & .082 & .091 & 1.041 & .300 \\
\hline & Fasilities & .473 & .080 & .566 & 5.917 & .000 \\
\hline
\end{tabular}

a. Dependent Variable: patient_satisfaction

Based on table 7 above, tangible variables have no significant effect on patient satisfaction tcount < ttable $(0.767<1.984)$ sig $0.445>0.05$, the reliability variable has no significant effect on patient satisfaction tcount $<$ ttable $(.525<1.984) \operatorname{sig} 0.601>0.05$, responsiveness has no significant effect on patient satisfaction tcount value $<$ ttable $(-.0247<1.984)$ sig $0.805>0.05$, assurance variable has no significant effect on patient satisfaction tcount < ttable $-239<1.984$ sig $0.811>0.05$, empathy variable has no significant effect on patient satisfaction tcount $<$ ttable $(1.041<1.984)$ sig $0.300>0.05$, facilities variable has significant positive effect on patient satisfaction tcount $>$ ttable $(5.917>1.984)$ sig $0,000<0.005$.

\section{Test f (Simultaneous Test)}

Table 8. F Test (Simultaneous Test)

\begin{tabular}{|l|l|r|r|r|r|r|}
\hline \multicolumn{2}{|l|}{ Model } & Sum of Squares & \multicolumn{1}{c|}{ df } & $\begin{array}{c}\text { Mean } \\
\text { Square }\end{array}$ & F & \multicolumn{1}{c|}{ Sig. } \\
\hline \multirow{3}{*}{1} & Regression & 55.643 & 6 & 9.274 & 8.112 & $.000^{\mathrm{b}}$ \\
\cline { 2 - 8 } & Residual & 104.031 & 91 & 1.143 & & \\
\cline { 2 - 8 } & Total & 159.673 & 97 & & & \\
\hline
\end{tabular}

a. Dependent Variable: patient_satisfaction

b. Predictors: (Constant), tangible, reliability, responsiveness, assurance, empathy, fasilities.

Based on the table 8 statistical test results simultaneously variable tangible (X1), reliability (X2), responsiveness (X3) assurance (X4) empathy (X5) and facilities (X5) have a significant positive effect on patient satisfaction fcount $>$ ftable $(8.112>1.35)$ sig $0,000<0.05$. 


\section{Discussion}

\section{H1: There is an influence between tangible on patient satisfaction}

Based on table 7 above, the effect of the dependent variable on patient satisfaction with tcount $<$ ttable $(0.767<1.984) \mathrm{sig}(0.455>0.05)$. Statistical test results can be concluded that H1 was rejected.

This means that partially the tangible variable does not have a significant effect on patient satisfaction. This means that what is seen directly in services to patients is not in line with expectations, far from what is desired by patients who are seeking treatment at a public health center. This illustrates that in community health centers health service providers do not provide information such as brochures, and other information media.

The results of this study support previous research conducted by (Kheng et al., 2010); (Yunus et al., 2013) but rejected the results of the study (Kazemi et al., 2013); (Krishna Naik et al., 2010); (Alghamdi, 2014); (Javed et al., 2019); (Andaleeb, 2001); (Aliman \& Mohamad, 2016); (Issadeen et al., 2019); (Nyoman et al., 2019); (Li et al., 2015) stated that Tanggible has a significant effect on patient satisfaction. In general, the results of his research that what was witnessed directly by patients in accordance with expectations such as the difficulty of getting information, the equipment used to function properly, the difficulty in the payment process.

\section{H2: There is an influence between reliabilty on patient satisfaction}

Based on table 7 above, the influence of reliability on patient satisfaction tcount $<\mathrm{t}$ table (0.525 1.984) sig 0.601>0.05. Conclusion $\mathrm{H} 2$ rejected. This means that partially, reliability does not have a significant effect on patient satisfaction. This means that medical officers in providing services are not immediately, the time required is not in accordance with what was promised and does not have a concern for patients.

The results of this study support the research (Rehaman B, 2018); (Yunus et al., 2013); (Aliman \& Mohamad, 2016). The results of this study reject previous studies (Kazemi et al., 2013); (Issadeen et al., 2019); (Nyoman et al., 2019); (Krishna Naik et al., 2010); (Javed et al., 2019); (Li et al., 2015); (Alghamdi, 2014); (Nasim \& Janjua, 2014) that reliability affects patient satisfaction, conclusions from previous research results that medical officers in providing health services immediately, services are carried out in accordance with the provisions and time required and have a patient's care.

\section{H3: There is an influence between responsiveness on patient satisfaction}

Table 7 above, the effect of responsiveness variables on patient satisfaction tcount $<$ ttable) $(-247<1.984)$ and significance level $(0.805>0.05)$. Conclusion H3 is rejected. That partially responsiveness is not a significant effect on patient satisfaction. This means that medical officers at the public health center in carrying out their duties are not quick to respond to patients, the clarity of information needed and willingness to help are not felt by patients.

The results of this study support research conducted by (Aliman \& Mohamad, 2016); (Li et al., 2015) that responsiveness has no significant effect on patient satisfaction. In contrast to 
the results of research conducted by (Rehaman B, 2018); (Kazemi et al., 2013); (Martins et al., 2015); (Krishna Naik et al., 2010); (Javed et al., 2019); (Alghamdi, 2014); (Yunus et al., 2013); (Issadeen et al., 2019); (Kheng et al., 2010) that responsiveness has a positive effect on patient satisfaction. It can be concluded that the results of his research the medical Satisfaction in carrying out the task has clarity in providing information, fast in providing services so patients do not wait long. Health workers, both nurses and doctors are willing to help patients and respond to the various kinds of questions from patients so that what is done all in accordance with what is expected by the patient.

\section{H4: There is an influence between assurance on patient satisfaction}

Based on table 7 above, the effect of assurance variables on patient satisfaction tcount < ttable) $(-239<1,984)$ sig $0.811>0.05$. Statistical test results can be concluded that $\mathrm{H} 3$ is rejected. This means that some assurance have no significant effect on patient satisfaction.

The results of this study support research (Li et al., 2015) that assurance have no significant effect on patient satisfaction. Research rejects research by (Aziz-Ur-Rehman \& Siddiqui, 2019); (Kazemi et al., 2013); (Krishna Naik et al., 2010); (Javed et al., 2019); (Andaleeb, 2001); (Yunus et al., 2013); (Aliman \& Mohamad, 2016); (Issadeen et al., 2019); (Kheng et al., 2010); (Nasim \& Janjua, 2014) the results of his research can be concluded that the assurance provides a synifical effect on patient satisfaction, this can be interpreted that the medical staff can and can be trusted, providing a sense of security in the delivery to patients having courtesy and friendliness in dealing with patients.

\section{H5: There is an influence between empathy on patient satisfaction}

Based on table 7 above, the effect of empahty variables on patient satisfaction tcount $>\mathrm{t}$ table $(1.041>1.984)$ sig $0.300>0.05$. Statistical test results can be concluded that H5 is rejected. This means that empahty is not partially significant effect on patient satisfaction. The results of this study can be interpreted that health care workers do not have empahty or attention to patients and do not understand well what is needed by patients and medical workers are rarely absent on the spot.

The results of this study are the results of previous studies such as (Rehaman B, 2018); (Martins et al., 2015); (Krishna Naik et al., 2010); (Javed et al., 2019); (Yunus et al., 2013); (Aliman \& Mohamad, 2016); (Kheng et al., 2010); (Issadeen et al., 2019); (Nasim \& Janjua, 2014) the conclusion of the empirical evaluation results in patient satisfaction. This can be interpreted that medical officers both nurses and doctors have a high sense of concern for the needs of patients, they can feel what the patient wants and understand what the patient needs.

\section{H6: There is an influence between the facilities on patient satisfaction}

Based on table 7 above, the effect of facilities variables on patient satisfaction tcount $>$ ttable $(5.917>1.984)$ and a significance level of $0.000<0.05$.

Statistical test results can be concluded that H6 is accepted. This means that partially significant positive effect on patient satisfaction. Statistical test results show that facilities owned by community health centers are felt to be adequate or in accordance with patient 
expectations. Because in a village, the only place to seek treatment for the community is that there is no private health center owned by the government.

The results of this study are in line with research (Ayranci \& Atalay, 2019) especially those relating to adequate parking lots and sufficient lighting. The results of this study also support the results of previous studies by (Javed et al., 2019) that the facilities has a significant effect on patient satisfaction, especially for private hospitals not owned by the government because based on consideration of costs that are more affordable for patients whereas if for private hospitals owned by patients can't afford to pay.

H7: There is an influence between tangible, reliability, responsiveness, assurance, empathy, and facilities on ppatient satisfaction

Based on table 8 above, simultaneously the influence of the variables of tangible, reliability, responsiveness, assurance, empathy and facilities value of fcount > Ftable $(8.112>1.35)$ sig $0,000<0.05$, conclusions of $\mathrm{H} 7$ are accepted. Statistical test results show that simultaneously all variables have a positive and significant effect on patient satisfaction. Therefore to see in detail must pay attention to the influence of each variable in order to get more precise conclusions in describing the actual conditions, so that it is also appropriate in taking action to be taken while still prioritizing the interests of patients.

\section{Conclusion}

Statistical test results show that all dimensions of service quality have no significant effect on patient satisfaction while facilities have a significant effect on patient satisfaction. The results of this study indicate that the quality of services available at public health centers owned by the government is not carried out properly, medical personnel in their work do not do work wholeheartedly only work merely carrying out their obligations so it is difficult to realize services that are in line with patient expectations. Facilities have a positive and significant impact on patient satisfaction, because the facilities owned by the community health center are owned by the government which has absolute authority.

\section{Limitations and Future Research}

This research is limited in the use of samples and research objects in community health centers in small areas. Furthermore, future researchers will be able to develop in larger hospitals and can consider other variables such as HR competency.

It is hoped that for future studies it can add even more community Health centers and the number of samples.

\section{References}

Alghamdi, F. S. (2014). The impact of service quality perception on patient satisfaction in government hospitals in Southern Saudi Arabia. Saudi Medical Journal, 35(10), 1271-1273.

Aliman, N. K., \& Mohamad, W. N. (2016). Linking Service Quality, Patients' Satisfaction and Behavioral Intentions: An Investigation on Private Healthcare in Malaysia. Procedia Social and Behavioral Sciences, 224(August 2015), 141-148. 
https://doi.org/10.1016/j.sbspro.2016.05.419

Andaleeb, S. S. (2001). Service quality perceptions and patient satisfaction: A study of hospitals in a developing country. Social Science and Medicine, 52(9), 1359-1370. https://doi.org/10.1016/S0277-9536(00)00235-5

Ayranci, E., \& Atalay, N. (2019). Demographic Determinants of Patient Satisfaction: A Study in a Turkish Context. International Journal of Academic Research in Business and Social Sciences, 9(6), 829-839. https://doi.org/10.6007/ijarbss/v9-i6/6041

Aziz-Ur-Rehman, M., \& Siddiqui, D. A. (2019). Relationship Between Flexible Working Arrangements and Job Satisfaction Mediated by Work-Life Balance: Evidence From Public Sector Universities' Employees of Pakistan. International Journal of Human Resource Studies, 10(1), 104. https://doi.org/10.5296/ijhrs.v10i1.15875

Chen, H., Li, M., Wang, J., Xue, C., Ding, T., Nong, X., Liu, Y., \& Zhang, L. (2016). Factors influencing inpatients' satisfaction with hospitalization service in public hospitals in Shanghai, People's Republic of China. Patient Preference and Adherence, 10, 469-477. https://doi.org/10.2147/PPA.S98095

Farzianpour, F., Byravan, R., \& Amirian, S. (2015). Evaluation of Patient Satisfaction and Factors Affecting It: A Review of the Literature. Health, 07(11), 1460-1465. https://doi.org/10.4236/health.2015.711160

Ghozali, I. (2009). Ekonometrika, Teori, Konsep dan aplikasi dengan SPSS 17. Badan Penerbit- UNDIP.

Hoodbhoy, Z., Rasheed, M. A., Sherali, F., Hussain, S., Hassan, R., Hameed, A., Ali, R., \& Hasan, B. (2020). A Framework for Improving Parent Satisfaction With the Inpatient Pediatric Admission Process: Experience From a Low-Resource Setting. Journal of Patient Experience, 237437352091632. https://doi.org/10.1177/2374373520916325

Indonesia, (2016). Regulation of the Minister of Health of the Republic of Indonesia Number 43 Year 2016 Regarding Minimum Service Standards in the Field of Health.

Issadeen, S., Aboobucker, I., \& Jamaldeen, R. (2019). An Assessment the Healthcare Service Quality in Selected Base Hospitals in RDHS Division Kalmunai-Sri Lanka. International Journal of Sciences: Basic and Applied Research (IJSBAR), 48(7), 65-75.

Javed, S. A., Liu, S., Mahmoudi, A., \& Nawaz, M. (2019). Patients' satisfaction and public and private sectors' health care service quality in Pakistan: Application of grey decision analysis approaches. International Journal of Health Planning and Management, 34(1), e168-e182. https://doi.org/10.1002/hpm.2629

Kazemi, N., Ehsani, P., Abdi, F., \& Bighami, M. K. (2013). Measuring hospital service quality and its influence on patient satisfaction: An empirical study using structural equation modeling. Management Science Letters, 3(7), 2125-2136. https://doi.org/10.5267/j.msl.2013.06.005 
Kheng, L. L., Mahamad, O., Ramayah, T., \& Mosahab, R. (2010). The Impact of Service Quality on Customer Loyalty: A Study of Banks in Penang, Malaysia. International Journal of Marketing Studies, 2(2). https://doi.org/10.5539/ijms.v2n2p57

Krishna Naik, C. N., Gantasala, S. B., \& Prabhakar, G. V. (2010). Service Quality (Servqual) and its effect on customer satisfaction in retailing. European Journal of Social Sciences, $16(2), 239-251$.

Li, M., Lowrie, D. B., Huang, C., Lu, X., Zhu, Y., Wu, X., Shayiti, M., Tan, Q., Yang, H., Chen, S., Zhao, P., \& He, S. (2015). Asian Paci fi c Journal of Tropical Biomedicine use of the ServQual scale. Asian Pacific Journal of Tropical Biomedicine, 5(6), 497-504. https://doi.org/10.1016/j.apjtb.2015.02.003

Lim, J. S., Lim, K. S., Heinrichs, J. H., Al-Aali, K., Aamir, A., \& Qureshi, M. I. (2018). The role of hospital service quality in developing the satisfaction of the patients and hospital performance. Management Science Letters, 8(12), 1353-1362. https://doi.org/10.5267/j.msl.2018.9.004

Martins, A. L., Carvalho, J. C. de, Ramos, T., \& Fael, J. (2015). Assessing Obstetrics Perceived Service Quality at a Public Hospital. Procedia - Social and Behavioral Sciences, 181, 414-422. https://doi.org/10.1016/j.sbspro.2015.04.904

Mpinga, E. K., \& Chastonay, P. (2011). Patient Satisfaction Studies and the Monitoring of the Right to Health: Some Thoughts Based on a Review of the Literature. Global Journal of Health Science, 3(1), 64-69. https://doi.org/10.5539/gjhs.v3n1p64

Mrayyan, M. T. (2006). Jordanian nurses' job satisfaction, patients' satisfaction and quality of nursing care. International Nursing Review, 53(3), 224-230. https://doi.org/10.1111/j.1466-7657.2006.00439.x

Nasim, K., \& Janjua, S. Y. (2014). Service quality perceptions and patients' satisfaction: A comparative case study of a public and a private sector hospital in Pakistan. International Journal for Quality Research, 8(3), 447-460.

Nyoman, N., Pramayanti, T., \& Arnaya, I. K. (2019). The Satisfaction Analysis of Kidney Failure Patients on the Quality of Hemodialysis Services in the National Health Guarantee Era ( JKN ) ( Case Study in Surya Husadha General Hospital Denpasar ). International Journal of Sciences: Basic and Applied Research (IJSBAR) ISSN, 48(7), 139-149.

Rahmani-Nejad, L., Firoozbakht, Z., \& Taghipoor, A. (2014). Service Quality, Relationship Quality and Customer Loyalty (Case Study: Banking Industry in Iran). Open Journal of Social Sciences, 02(04), 262-268. https://doi.org/10.4236/jss.2014.24028

Rashidi, H. S. Al, \& Sarayreh, A. A. AL. (2019). Organizational Flexibility and Its Impact on the Service Quality: A Survey Study on Communication and Information Technology Regulatory Authority in Kuwait. International Journal of Human Resource Studies, 9(3), 116. https://doi.org/10.5296/ijhrs.v9i3.14797

Rehaman B, H. M. (2018). The Impact of Service Quality Dimensions on Patient Satisfaction 


\section{Macrothink}

International Journal of Human Resource Studies

ISSN 2162-3058 2020, Vol. 10, No. 3

in the Private Healthcare Industry in Pakistan. Journal of Hospital \& Medical Management, 04(03), 1-8. https://doi.org/10.4172/2471-9781.100048

Tarjo. (2019). Metode Penelitian Sistem 3x Baca (1st ed.). Deepublish. https://play.google.com/store/books/details/Tarjo_Metode_Penelitian_Sistem_3x_Baca?id=Si zGDwAAQBAJ

Yunus, N. M., Latiff, D. S. A., Din, S. C., \& Ma'on, S. N. (2013). Patient Satisfaction with Access to 1Malaysia Clinic. Procedia - Social and Behavioral Sciences, 91, 395-402. https://doi.org/10.1016/j.sbspro.2013.08.436

Zarei, A., Arab, M., Froushani, A. R., Rashidian, A., \& Tabatabaei, S. M. G. (2012). Service quality of private hospitals: The Iranian Patients' perspective. BMC Health Services Research, 12(1). https://doi.org/10.1186/1472-6963-12-31

\section{Copyright Disclaimer}

Copyright for this article is retained by the author(s), with first publication rights granted to the journal.

This is an open-access article distributed under the terms and conditions of the Creative Commons Attribution license (http://creativecommons.org/licenses/by/4.0/). 